\title{
REMOTE SENSING OF FAST ICE IN LÜTZOWHOLMBUKTA, EAST ANTARCTICA, USING SATELLITE NOAA-7, 8 AND AIRCRAFT
}

\author{
(Abstract) \\ by \\ S. Mae \\ (Department of Applied Physics, Faculty of Engineering, Hokkaido University, Sapporo 060, Japan) \\ and \\ T. Yamanouchi and Y. Fujii \\ (National Institute of Polar Research, Tokyo 173, Japan) \\ In 1983, before the break-up of the fast ice in April, \\ a distinctive increase of the infra-red radiance (NOAA \\ AVHRR) was observed, even though the aerial observation \\ showed no change. The increase of the radiance was \\ estimated to be $5^{\circ} \mathrm{C}$. It was in this area, where the \\ higher infra-red signal was observed, where the fast ice \\ broke up. In December, in the central part of the northern \\ area of the fast ice, the hummock-ice zone formed in a \\ triangular shape. Before the hummock-ice zone floated out, \\ observation of the infra-red radiance showed that the \\ temperature of the ice had decreased by $3^{\circ} \mathrm{C}$.
}

\begin{abstract}
Lützowholmbukta, East Antarctica, is covered by fast ice except during a short period in April and May, but occasionally the ice cover breaks up and floats out of the bay.

The fast ice was observed every day using NOAA-7, 8 infra-red imagery. The satellite signal was received at Syowa Station, located on Ongul Island. In addition, aerial photographs and video pictures were taken using aircraft every fortnight.
\end{abstract}

\section{ESTIMATION OF SNOW-MELT RUN-OFF DURING PRE-MONSOON MONTHS IN BEAS SUB-BASIN USING SATELLITE IMAGERY}

\section{(Abstract)}

by

\author{
K.P. Sharma and P.K. Garg
}

(Civil Engineering Department, University of Roorkee, Roorkee, India)

\begin{abstract}
The increasing demand for water, coupled with the construction of multi-purpose reservoirs to control and regulate snow-melt run-off, requires accurate stream-flow forecast. For making an accurate prediction of spring run-off, information on the amount of snow accumulation in winter is necessary; this may be achieved through remote-sensing techniques in any inaccessible region.

This paper outlines the snow-melt run-off study carried out in a part of Beas basin, India, using Landsat imagery for the years 1973, 1975, 1976, and 1977. The Beas basin lies between long. $76^{\circ} 56^{\prime}$ to $77^{\circ} 52^{\prime} \mathrm{E}$. and lat. $31^{\circ} 30^{\prime}$ to $32^{\circ} 25^{\prime} \mathrm{N}$., covering an area about $4900 \mathrm{~km}^{2}$, of which $1400 \mathrm{~km}^{2}$ is permanently covered by snow. The gradual melting of snow accumulated over the catchment area during the winter months is responsible for the perennial character of the Beas River.

Photohydrological investigation of the part of the Beas basin up-stream of Barji was carried out and a study was made for the estimation of the snow-melt run-off during the pre-monsoon period in the sub-basin up-stream of Manali. For this purpose, the sub-basin has been divided into permanent and temporary snow-covered zones. The
\end{abstract}

degree-day method and the melt due to rainfall on snow have been used to estimate snow-melt run-off. The routing of snow-melt, after accounting for losses as well as the run-off from the excess rainfall from the permanent and temporary snow-covered areas, has also been done taking the recession coefficient $\mathrm{K}$ as 0.90 , and the excess rain from the non-snow-covered areas has been assumed to contribute directly to the run-off for that day. Run-off coefficients of 0.595 for rainfall on the snow-covered areas and 0.278 for rainfall on the non-snow-covered areas have been determined.

Reference can be made to similar work in India and Pakistan to establish the relationship between the snow cover and the cumulative discharges for the months of March, April, and May of the years 1973, 1975, 1976, and 1977 , and an exponential trend was observed with the help of Landsat imagery. Furthermore, the snow-covered areas as determined from bands 5 and 7 of the Landsat imagery, for the same day, showed a linear trend.

The analysis of the results shows that remote-sensing data used in conjunction with conventional methods are likely to improve the accuracy of the snow-melt forecasts in remote areas like the Himalayan catchments. 